\title{
Work in Projects against Forms of Work - Polish Perspective
}

\author{
Katarzyna Piwowar-Sulej \\ Department of Labour and Industrial Relations, Wroclaw University, Wroclaw, Poland \\ *Corresponding Author: katarzyna.piwowar@ue.wroc.pl
}

Copyright $@ 2014$ Horizon Research Publishing All rights reserved.

\begin{abstract}
The article asks the question whether work in projects is a new form of work. In order to find an answer to this question the components of forms of work have been presented. They were based upon the division by the forms of employment, forms of work organization and forms of organization of working time. Literature studies were complemented by the results of empirical research conducted with 22 project managers. The analysis took into account the Polish context of the way companies cooperate (some cultural and legal aspects).
\end{abstract}

Keywords Form of Work, Work Arrangements, Form of Employment, Project, Polish Conditions

\section{Introduction}

In the world characterized by rapid changes, establishing the project teams becomes the domain of many organizations. The projects concern introduction of new products or services or modifications of the processes. They are also used in change management.

Project is a unique and not a recurring activity which should have well-defined objective. It has a temporary organization with defined set of budget, resourcing and timescale constraints [1]. Realization of the projects is based upon the work in a team - specially established for that purpose.

It may be stated generally that work in projects is characterized by temporariness, time pressure, indefiniteness of the tasks and variable personal configurations. The indicated characteristics differentiate the work in projects from the routine work in functional department. But is work in project a new form of work? Where should the work in project be placed among the form of work (form of work arrangements) broadly described in the literature on the management? Answering the research questions above has become the aim of this paper.

\section{Materials and Methods}

The research problem relates to the identification, if work in project is a new form of work. The research objective was to identify the important issues leading to qualify (or not) work in projects for a new form of work. To accomplish this objective, the author developed guiding propositions to guide the research based on what has been learned from the literature. There have been presented the components of forms of work, based upon the division by the forms of employment, forms of work organization and forms of organization of working time. The further analysis is based upon such methods like the studies on the literature on the management and own empirical research.

The research was carried out in accordance with the general model shown in fig. 1. The research procedure included particularly such steps as: the formulation of the research problem, statement of research questions, the selection of research methods, developing and verification of a research tool (interview questionnaire, analysis of data and information which was obtained during the research, coming to the conclusions.

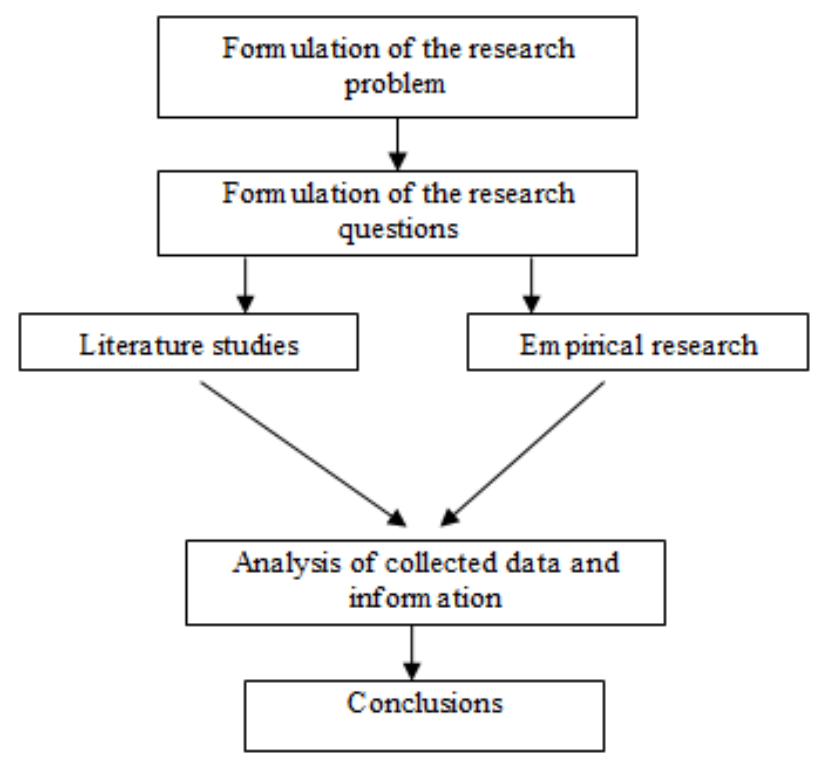

Source: own work

Figure 1. Research procedure 
It should be stressed here that the presented results refer to the initial empirical research and therefore they are only demonstrative and shall be further verified empirically. It is hard to determine how many project teams exist in Poland at specified time. The indicated research (direct semi-structured interviews) was carried out in 2012 with 22 project managers from different organizations. The research unit is an enterprise. The research sample consists of only 22 representatives. This is not a representative sample. Consequently, the hypotheses have been replaced with research questions:

1. Is work in project a new form of work?

2. Where should the work in project be placed among the form of work arrangements?

Those managers work correspondingly in 10 the so called project enterprises in the strict sense (mainly of the IT and power industries) and 12 non-project companies (in which, however, the projects are managed, mainly production and financial companies).

\section{Brief characteristics of forms of work}

As it is indicated in the introduction, it has been assumed that the forms of work may be divided as presented in fig.2. In the subsequent part of the paper the components of the work forms are characterized successively.

\subsection{Forms of Employment}

The method of work performance is expressed by the forms of employment. The types of the forms of employment in Polish conditions are presented in fig.1. It should be stressed that the terminology concerning employment forms remains so far not completely organized.

First of all, the work in Poland may be performed under the labor relations (employment contract). It may be permanent (indefinite employment contract) or temporary (fixed-term employment contract, contract for the time of performance of specified work, contract for the period of replacement). A characteristic attribute of the labor relations is that the work is performed permanently and against payment. The employee is obliged to execute the orders of the employer and the work is performed within strictly specified time and in the indicated location.

The other forms (non-regular or atypical) of the employment appear when the working person is not an employee in legal meaning but performs work under a relatively constant legal and organizational relations with the entity ordering the work. The legal relationship between the parties in those forms of work is of the civil (obligation) nature. The person performing the work does not have the rights of the employee. It mainly concerns the right to the vacation and protection of the employment in special cases. The obligation of social insurance - particularly the sickness insurance - is undertaken by the person performing the work in many cases. The self-employed persons incur all tax and social insurance burdens.

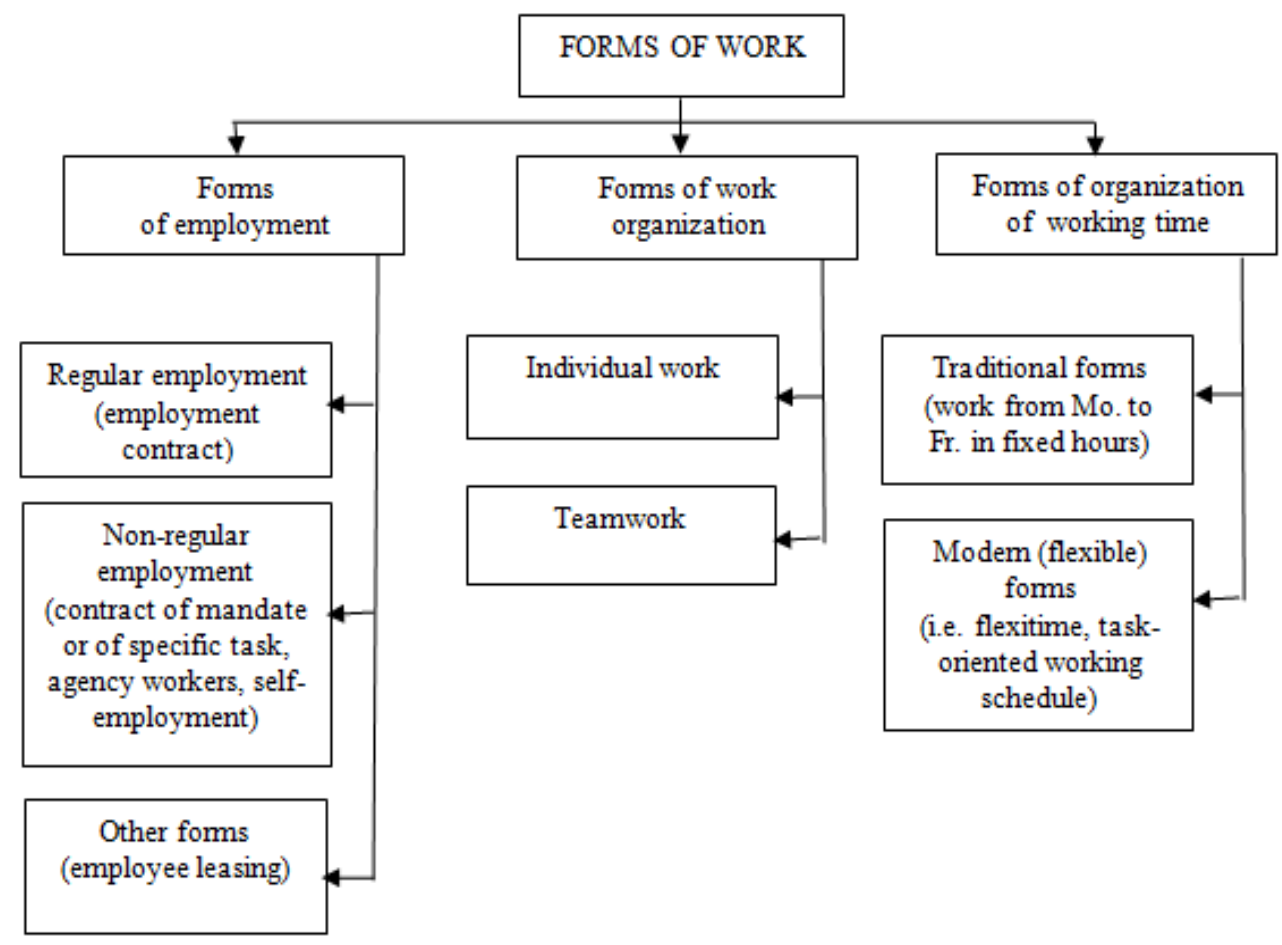

Source: own work using [2]

Figure 2. Components of forms of work in Poland 
Finally, the employee leasing may be distinguished from the other forms. This form is defined as an arrangement in which a firm (called subscribing firm) transfers its employees to another firm (called leasing firm). The subscribing firm leases its employees back as employees of the leasing firm and usually pays more for their services than their salaries at the time of transfer. This way the payroll and associated expenses and taxes of the leased employees become the leasing firm's liabilities [3].

It is hard to compare the Polish system of employing people with employment solution which are practiced in other countries. For example the British system does not know the notion of other employment agreements. In Great Britain there are employees contracted based on an agreement (employees), self-employed, outsourced workers and agency workers [4]. In United States of America the economic work can be divided into two groups: employment and contract work. Employment includes a direct employment and a coemployment (leased employees, agency workers, professional employee organizations). Contract work can be further divided into direct contracting and subcontracting [5]. The contract of mandate or a contract of specific tasks are the employment solution used only in Poland.

\subsection{Forms of Work Organization}

Forms of work organization are defined as the specified degree of organizational consolidation [6]. Thus, the first basic form of work is the individual work. When performing the individual work, each employee individually realizes the tasks given to him by the superior, using his potential.

Teamwork is defined as the case of collective actions in which the performance of certain systematic actions and operations is entrusted to the specified group of people, among whom there are direct production (work) connections [7]. It becomes necessary when it is impossible to allocate the tasks to the individual workers, when a process is of continuous nature, when the amount of work exceeds the capacities of single person or there is a large interdependence of the realized tasks.

A strong point of the teamwork is that the work may be distributed more advantageously, there is possibility of reciprocal help, collective solution of the problems which appear at work, thus the more numerous ways of viewing of the problems, easier flow of information and communication, better exchange of the experience, possibility of drawing the inspiration and learning from the other persons, easier dealing with the differences resulting from the individual approaches, possibility of taking the decisions which are more impartial, worked out and of better quality [8, 9].

Making the balance of strong and weak points of the teamwork, it should be stated that this former prevail definitely. Moreover, the phenomena which may occur as the result of the negative sides of the team work, may be prevented or their results may be reduced by their earlier identification.
Let's consider the issue of trust. It has been known that lack of trust makes effective teamwork impossible. In this connection it is worthwhile to mention the result of research on certain features of Polish culture carried out by $\mathrm{J}$. Czapiński and T. Panek as well as The Hofstede Centre. They seem to confirm a commonly held belief that "Polish nationals don't know how to organize themselves and cooperate effectively in situations other than strike or protest" [10]. Polish culture tends to be male dominated (it means greater competition, the importance of status) and individualistic ("my welfare is more important than that of society as a whole" attitude). Consequently teamwork and especially real team building (as defined by J.R. Katzenbach and K.D. Smith) is a considerable challenge (for more see [11]). According to J.R. Katzenbach and K.D. Smith, a real team is a small group of people with complementary skills, joint approach to work, who are truly involved in the actions aiming at reaching the common general goal and the detailed goals (work discipline) for which all feel jointly responsible [12].

\subsection{Forms of organization of Working Time}

Working time is most often defined as time in which an employee is at the disposal of an employer, which means readiness to do tasks commissioned by an employer. As it has been indicated in fig.1, the forms of organization of working time may be divided into the traditional and modern (flexible) ones. In the traditional model of the organization of working time it is assumed that both the technology and work organization require unified principles of the regulation of that time. Those principles are listed to be [13]:

- principle of uniformity (the same regulations for the entire working place),

- principle of punctuality (strict observance of the hours of commencement and termination of work),

- principle of authority (the employee is impossible to form his working time),

- principle of taboo (no possibility of spreading the other regulations of working time).

Making the working time flexible means mainly the individualization of the solutions relating to the forming of that time. The flexible forms of organization of the working time possible to be used in Polish conditions include (for more see [14]):

a) compressed working hours,

b) tandem job or job sharing,

c) flexi-time work (a worker starts and finishes work within the specified time intervals),

d) staggered hours (the rules set up with the employer become valid i.e. in a particular quarter of the year),

e) individual working hours (the employee specifies how many hours he wants to work in a week, a month, etc.).

Discussions of motivation for flexible organization of working time use tend to converge on two broad categories: life management and work-related motives. The label 'life 
management motives' is used as an umbrella term for any motive that helps individuals better manage the intersection of their work and personal life. Examples include balancing work and family, childcare, to reduce commute time, or to attend to personal matters. In contrast, work-related motives are those that are aimed at increasing one's efficiency or productivity at work [15].

Nationwidely, the flexible solutions are introduced to minimize the unemployment. In Poland, in the year 2013 there were introduced subsequent changes to the Labour Code, concerning making the working time flexible due to the existing global economic crisis.

\section{Work in Projects against the Previously Presented Forms of Work - a Discussion}

\subsection{Forms of Employment in Projects}

It is characteristic for the projects that both the project managers and all persons performing the project works may be: a) connected with the enterprise independently on the project,

b) acquired only for the time of the project or shorter period (part of the project).

In the reference literature there have not been found the results of the studies on the most frequent forms of employment in projects or proportions between the workers employed permanently in the organizations where the projects are realized and persons involved temporarily in the projects. J.R. Keegan and M. Turner "suggest" that employing $20 \%$ to $40 \%$ of the contract personnel in an organization is a good method to deal with the uncertainty concerning the desired amount of the resources involved in a project [16]. Those proportions surely depend on how much „of project type" the particular organization is.

The nature of the tasks performed as a part of the project and - the demand for specific competencies connected with that - is one of the most fundamental factors determining the method of the employment in a project. However, in Polish conditions it is possible to use the specified, law-established forms of relation between the enterprise and the participants of the project. Those forms are listed in table 1 .

Table 1. Possible forms of the employment in the projects realized in Poland

\begin{tabular}{|c|c|c|}
\hline $\begin{array}{l}\text { Form of connection } \\
\text { between the enterprise and } \\
\text { project participant }\end{array}$ & Brief characteristics of the employment form & $\begin{array}{l}\text { Popularity of use of the particular form } \\
\text { of employment in projects (number of } \\
\text { affirmative replies, } n=22 \text { ) }\end{array}$ \\
\hline $\begin{array}{l}\text { employment contract for } \\
\text { the indefinite period }\end{array}$ & $\begin{array}{c}\text { full employees' rights (resulting from the Labour Code and regulations of } \\
\text { Minister of Labour and Social Policy), } \\
\text { the length of the notice period is up to } 3 \text { months (depending on the period } \\
\text { of service at the particular employer), } \\
\text { termination of the contract requires the justification }\end{array}$ & $100 \%(22)$ \\
\hline $\begin{array}{l}\text { fixed-term employment } \\
\text { contract }\end{array}$ & $\begin{array}{c}\text { full employees' rights, } \\
\text { specified date of contract termination, } \\
\text { the length of the notice period is } 2 \text { weeks. (if that is stipulated in the } \\
\text { contract and the duration of the contract exceeds } 6 \text { months), }\end{array}$ & $100 \%(22)$ \\
\hline $\begin{array}{l}\text { contract for the period of } \\
\text { replacement }\end{array}$ & $\begin{array}{l}\text { employees' rights, however the contract does not protect the pregnant } \\
\text { employee against the termination of labour relations and the dismissed } \\
\text { employee is not entitled to payable days for searching for a job, } \\
\text { end of the contract specified by the fact of the return of the employee being } \\
\text { replaced, } \\
\text { termination of the contract requires no justification, } \\
\text { the notice period is } 3 \text { days }\end{array}$ & - \\
\hline contract of mandate & $\begin{array}{l}\text { no employees' rights, } \\
\text { civil law agreement - the so called agreement of due diligence, } \\
\text { no obligation of personal performance of the work }\end{array}$ & $10(45 \%)$ \\
\hline self-employment & $\begin{array}{c}\text { no employees' rights } \\
\text { civil law agreement }\end{array}$ & $20(91 \%)$ \\
\hline $\begin{array}{l}\text { Form of connection } \\
\text { between the enterprise and } \\
\text { project participant }\end{array}$ & Brief characteristics of the employment form & $\begin{array}{l}\text { Popularity of use of the particular form } \\
\text { of employment in projects (number of } \\
\text { affirmative replies, } n=22 \text { ) }\end{array}$ \\
\hline contract for a specific work & $\begin{array}{c}\text { no employees' rights } \\
\text { civil law agreement - the so called agreement of result, }\end{array}$ & $1(5 \%)$ \\
\hline employee leasing & $\begin{array}{l}\text { temporary leasing of the employees from a temporary employment agency, } \\
\text { length of the employment period up to } 18 \text { months, } \\
\text { short notice period, } \\
\text { limited right to the vacation comparing to the employment contracts, } \\
\text { no need to justify the contract termination, } \\
\text { subject to the Act on Temporary Employment }\end{array}$ & $12(55 \%)$ \\
\hline
\end{tabular}


Not all forms of work contracts established in Polish law may be used in projects. That concerns the so called agreement for the time of performance of the specified work. Usually such agreement is concluded in situations when the parties of the labor relations want to limit the duration of the agreement but cannot precisely define its validity period at the moment of concluding. The projects, however, have the time of the realization precisely specified.

Contract for the period of replacement is not used due to the fact that there is not such need or because of the insufficient competencies of the employees who perform the work under that contract for the units of the permanent structure of the enterprise. Other forms of the relations between the enterprise and the participants of the project, presented in this paper (employment contract for indefinite period or fixed period, self-employment, contract of mandate or contract for a specific work and employee leasing) are used to a greater or lesser degree.

It may be concluded from the carried out own empirical research that the organizations in which the respondents-managers work rely in projects mainly on permanent employees, that means upon the persons working for the enterprise independently on the fact of realizing of the project. That is undoubtedly conducive to creation of common organizational culture and improvement and maintaining the high standards of subsequent project actions.

\subsection{Work in Projects Individual or Team Work?}

It is worth to indicate here that establishing the project teams demonstrates the promotion of teamwork. The particular project team may not be the real team defined by J.R. Katzenbach and K.D. Smith indeed. Whether the cooperation between team members appears and what form it takes, depends on such objective factors as i.e. the structure of a team project (see table 2). That structure, in turn, is adapted mainly to the subject (aim and scope) of the project.

It can be stressed that even in the collective (egoless) model of team structure (which suggests intensive communication and collaboration) both individual and team work may occur. The nature of the interaction between team members can be most fully identified on the basis of work break down strukture (WBS).

\subsection{Organization of Working Hours in Projects}

As it was indicated in the introduction of the paper, the projects are realized under the time pressure. Therefore, they are connected with the necessity of overtime work. Thus, the instruments of motivating to work, which are within the decision area of the project manager, include making available to employees to plan their working hours more flexibly and the award in the form of a day off for overtime work (for more see [19]).

It results from the own research carried out in 2012 that the regulations concerning the working hours during the participation in projects are the same as during the work in the functional department. That concerns both the project and non-project enterprises. The award in the form of a day off for the overtime work is an employee privilege established in the par. $151^{2}$ of the Labour Code [20].

In the non-project organisations with the matrix structure it is the line manager who cares for the conformity of working hours with the valid system of working time. It is the manager who accepts the vacations and enables the "compensation" of the overtime. Therefore, it seems that the award in the form of a day off for overtime work appears to be within the decision area of the project manager rather in the situation of temporary, full delegation of an employee to work in a project.

Table 2. Structure of a team work and the resulting nature of cooperation between the persons performing the works

\begin{tabular}{|c|c|}
\hline $\begin{array}{l}\text { Type of the structure of a } \\
\text { project team }\end{array}$ & Nature of cooperation within the team \\
\hline isomorphic & $\begin{array}{l}\text { individual actions } \\
\text { no cooperation between the members of the project team or cooperation resulting only from the needs of the members } \\
\text { of the project team }\end{array}$ \\
\hline speciality & $\begin{array}{l}\text { individual actions } \\
\text { no cooperation or cooperation resulting only from the needs of the members of the project team }\end{array}$ \\
\hline egoless & $\begin{array}{l}\text { the entire team is collectively responsible for the success of the project, which creates the cooperation } \\
\text { team members are induced to communicate and cooperate intensively - that influences the team integration } \\
\text { in the case of numerous team there may appear too many channels of communication }\end{array}$ \\
\hline surgical & $\begin{array}{l}\text { the success of the project depends on one person - the boss } \\
\text { no cooperation between the members of the team at all or cooperation resulting only from the needs of the members } \\
\text { of the project team }\end{array}$ \\
\hline
\end{tabular}

Source: [18] 


\section{Conclusion}

Performance of the works as projects becomes more and more popular. That allows achieving the partial goals of the enterprise more efficiently; therefore it has the indirect effect upon the more efficient realization of strategic goals. Work in projects differs from the routine work in line units. That is why that phenomenon should be the subject of scientific reflection and empirical research.

In the paper the question whether the work in projects is the new form of the work has been asked.. Based upon the conducted considerations it may be stated that work in project is not a new form of the work. By analysing the particular components of forms of work arrangements, it may be stated that in the projects there are used various forms of employment, form of work organization and forms of the organization of the working time. The selection of the solution depends on such issues as the aim of the project, availability of skilled persons, legal regulations and organisational culture of the enterprise in which the projects are realised.

\section{REFERENCES}

[1] R. Jones. Project Management Survival. A practical guide to leading, managing and delivering challenging projects, Kogan Page Limited, London 2007, pp. 5-6

[2] D. Bąk-Grabowska. Kobiety o elastycznych formach pracy interpretacja wyników badań empirycznych (Women opinion about flexible forms of work arrangements - the interpretation of empirical research), in: Zarządzanie zasobami ludzkimi w praktyce, ed. Cz. Zając, Zeszyty Naukowe Wyższej Szkoły Bankowej we Wrocławiu No. 30, Wrocław 2012, p. 13

[3] http://www.businessdictionary.com/definition/employee-leas ing.html (18.02.2012)

[4] P. Leighton, M. Syrett, R. Hecker, P. Holland, Out of the Shadows. Managing self-employed, agency and outsourced workers, Elsevier Ltd., Burlington 2007, pp.14-15

[5] P. Cappelli, Jr Keller, CLASSIFYING WORK IN THE NEW ECONOMY, "Academy of Management Review". 2013, Vol. 38 , No. 4 , p. 577

[6] Zarządzanie pracą. Organizowanie, planowanie, motywowanie, kontrola (Work Management. Organizing, Planning, Motivating, Controlling), ed. Z. Jasiński, Wydawnictwo Placet, Warszawa 1999, p. 29.

[7] Zarządzanie pracą. Organizowanie, planowanie, motywowanie, kontrola (Work Management. Organizing, Planning, Motivating, Controlling), ed. Z. Jasiński,
Wydawnictwo Placet, Warszawa 1999, p. 31

[8] Zarządzanie pracą. Organizowanie, planowanie, motywowanie, kontrola (Work Management. Organizing, Planning, Motivating, Controlling), ed. Z. Jasiński, Placet, Warszawa 1999, p. 39

[9] D.A. Baldwin, R.L. Migneault, Humanistic Management by Teamwork: An Organizational and Administrative Alternative for Academic Libraries, Libraries Unlimited Inc., Englewood 1996, p. 19

[10] J. Czapiński, T. Panek, Diagnoza Społeczna 2011 (Social diagnosis 2011), Warszawa 2011, p. 283

[11] J.R. Katzenbach, K.D. Smith, The Wisdom of Teams. Creating the High-Performance Organizations, Harvard Business School Press, McKinsey and Company Inc., USA 1993, p. 21

[12] Szerzej zob. M. Zaborek, Praca zespołowa w polskich organizacjach (Team work in the Polish organizations), Online available fromhttp://blog.weknowhow.pl/wp-content/uploads/2012/07/ Praca-zespo\%C5\%82owa-w-polskich-organizacjach.pdf

[13] Potencjał pracy przedsiębiorstwa (Work Potential of an Enterprise), ed. M. Gableta, Wyd. AE im. O. Langego we Wrocławiu, Wrocław 2006, p. 123

[14] Potencjał pracy przedsiębiorstwa (Work Potential of an Enterprise), ed. M. Gableta, Wyd. AE im. O. Langego we Wrocławiu, Wrocław 2006, pp. 125-127

[15] K. M. Shockley, T. D. Allen, Motives for flexible work arrangement use, "Community, Work \& Family" Vol. 15, No. 2, May 2012, pp. 219-220

[16] J.R. Turner, M. Huemann, A. Keegan, Human Resources management in the Project-Oriented Organization, PMI, Newtown Square, Pennsylvania 2008, p. 20

[17] K. Piwowar-Sulej, Formy zatrudniania uczestników projektów (Forms of employment of project participants), „Nauki o zarządzaniu (Management Science)” 2013, pp. $52-53$

[18] K. Piwowar-Sulej, Organizacyjne uwarunkowania współpracy w zespole projektowym (Organisational aspects of cooperation in project teams), in: Formy i uwarunkowania współpracy we współczesnej gospodarce. Studia ekonomiczne regionu łódzkiego. Wydanie specjalne, TNOiK, Łódź 2012, p. 453

[19] K. Piwowar-Sulej, A. Pietroń-Pyszczek, Motywowanie do pracy $\mathrm{w}$ zespołach projektowych (Motivating in project teams), in: Zarządzanie zasobami ludzkimi w praktyce, ed. Cz. Zając, Zeszyty Naukowe Wyższej Szkoły Bankowej we Wrocławiu No. 30, Wrocław 2012, p. 17

[20] Labour Code. Legal status as of the date of 1 January 2013, Supplement No.2 to the biweekly magazine „Ubezpieczenia i Prawo Pracy” No. 2 (332), 10 January 2013, p. 51 